\title{
Occurrence, ecological function and medical importance of dermestid beetle hastisetae
}

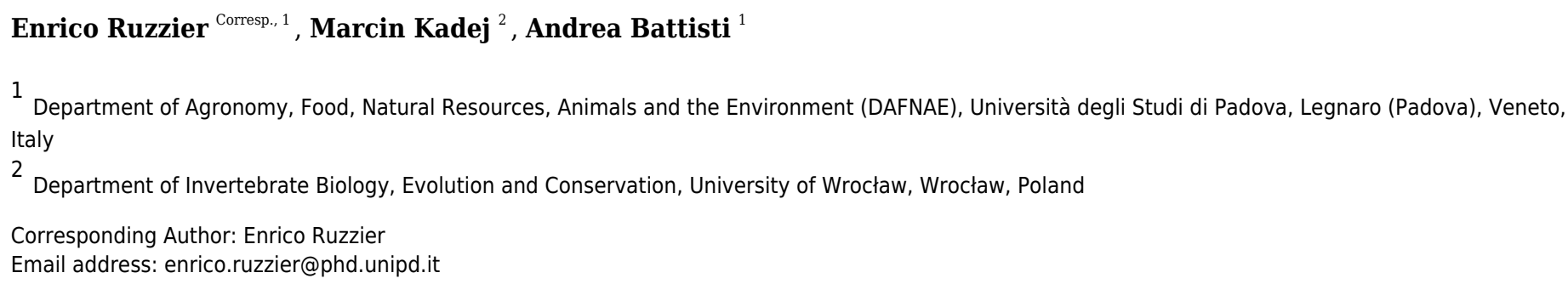

Hastisetae are a specific group of detachable setae characterizing the larvae of Megatominae (Coleoptera: Dermestidae), commonly known as carpet and khapra beetles. These setae are located on both thoracic and abdominal tergites and they are the primary defense of the larva against invertebrate predators. According to previous studies, the main purpose of hastisetae is to work as a mechanical obstacle, but they are also capable to block and kill a predator. Hastisetae, single or aggregate, function as an extremely efficient mechanical trap, based on an entangling mechanism of cuticular structures (spines and hairs) and body appendages (antennae, legs and mouthparts). It is believed that this defensive system evolved primarily to contrast predation by invertebrates, however it has been observed that hastisetae may affect vertebrates as well. Although information on the impacts of vertebrate predators of the beetles is lacking, hastisetae have been shown to be a possible threat for human health as an important contaminant of stored products (food and fabric), work and living environment. Review of old and recent literature on dermestid larvae has revealed that despite these structures indicated as one of the distinctive characters in species identification, very little is known about their ultrastructure, evolution and mechanism of action. In the present work, we will provide the state of the art knowledge on hastisetae in Dermestidae and we will present and discuss future research perspectives intended to bridge the existing knowledge gaps. 
1 Occurrence, ecological function and medical importance of dermestid beetle hastisetae 2

3 Enrico Ruzzier ${ }^{1}$, Marcin Kadej $^{2}$, Andrea Battisti ${ }^{1}$

4

$5{ }^{1}$ Department of Agronomy, Food, Natural Resources, Animals and the Environment

6 (DAFNAE), Università degli Studi di Padova, Padova, Italy.

7

$8{ }^{2}$ Department of Invertebrate Biology, Evolution and Conservation, University of Wrocław, 9 Wrocław, Poland.

10

11 Corresponding Author:

12 Enrico Ruzzier,

13 Department of Agronomy, Food, Natural Resources, Animals and the Environment (DAFNAE),

14 Viale dell'Università 16, Legnaro, 35020 Padova, Italy.

15 Email address: enrico.ruzzier@phd.unipd.it; symphyla@gmail.com

16

17 


\section{Abstract}

19 Hastisetae are a specific group of detachable setae characterizing the larvae of Megatominae

20 (Coleoptera: Dermestidae), commonly known as carpet and khapra beetles. These setae are

21 located on both thoracic and abdominal tergites and they are the primary defense of the larva

22 against invertebrate predators. According to previous studies, the main purpose of hastisetae is to

23 work as a mechanical obstacle, but they are also capable to block and kill a predator. Hastisetae,

24 single or aggregate, function as an extremely efficient mechanical trap, based on an entangling

25 mechanism of cuticular structures (spines and hairs) and body appendages (antennae, legs and

26 mouthparts). It is believed that this defensive system evolved primarily to contrast predation by

27 invertebrates, however it has been observed that hastisetae may affect vertebrates as well.

28 Although information on the impacts of vertebrate predators of the beetles is lacking, hastisetae

29 have been shown to be a possible threat for human health as an important contaminant of stored

30 products (food and fabric), work and living environment. Review of past and recent literature on

31 dermestid larvae has revealed that despite these structures indicated as one of the distinctive

32 characters in species identification, very little is known about their ultrastructure, evolution and

33 mechanism of action. In the present work, we will provide the state of knowledge on hastisetae

34 in Dermestidae and we will present and discuss future research perspectives intended to bridge

35 the existing knowledge gaps.

37 Subjects Evolutionary Biology, Morphology, Pest Management, Zoology

38 Keywords Allergy, Coleoptera, Dermestidae, Ecology, Health, Insects, Systematic, Zoology 


\section{Introduction}

42 The cuticle plays a pivotal role in several aspects of arthropod biology, representing the interface 43 between the living tissue and the external environment (Bereiter-Hahn et al., 1984). Thus, the 44 cuticle displays structural specializations such as denticles, setae, setulae and spines, all with specific functions (Winterton, 2003). Correlations between structure and function are well studied especially in insects (Neville, 1975) and crustaceans (Garm, 2004a, b; Garm and Watling, 2013). Setae are multicellular protuberances on the cuticle, used primarily for mechanoreception (Steinbrecht, 1984; Keil and Steinbrecht, 1984; Keil, 1997; Winterton,2003; Barth, 2004). In all groups of arthropods, the role of setae has evolved from simple mechanoreception to various other functions, including defense (Battisti et al., 2011), locomotion (Lebarque et al., 2017), prey capture (Felgenhauer et al., 1989), pheromone dispersal (Stainbrecht, 1984), sexual display (Perez-Miles et al., 2005), preening (Felgenhauer et al., 1989), and camouflage (Zeledon et al., 1973; Hultgren and Stachowicz, 2008; Stevens and Merilaita, 2009). Detachable setae are true setae characterized by the loss of the neural connection and the detachment of the base of the hair from the integument (Battisti et al., 2011). The proximal end of each seta is attached to an integument stalk or inserted into a socket and can be easily removed with any kind of mechanical stimulation. This class of hairs has evolved as a defensive structure against predation at least four times in Arthropoda. The class is subdivided in two main morpho-ecological groups: urticating hairs and anchor-like setae. Urticating hairs are characterized in some Lepidoptera families such as the Nodotontidae (subfamily Thaumetopoeinae), Erebidae, Saturniidae and Zygenidae and the spider family Theraphosidae (sub. fam. Theraphosinae) (Battisti et al., 2011) and are described to protect from vertebrate predators (Battisti et al., 2011; Bertani and Guadanucci, 2013). Anchor-like setae are characterized in some larvae of Dermestidae (Insecta: Coleoptera) and Polyxenidae (Myriapoda: Polyxenida) where they work as entangling mechanism against invertebrates (Nutting and Spangler, 1969; Eisner et al., 1996). Dermestid detachable setae (hastisetae) are used by the larvae as an active trapping system against arthropod predators (Nutting and Spangler, 1969). These specialized setae are almost exclusively prerogative of Megatominae, the most species rich group in the entire family (Hava, 2015). The mechanism of action of hastisetae and their microstructure remains largely obscure and restricted to few case studies (Nutting and Spangler 1969; Mills and Partida, 1976); furthermore, how the evolution of hastisetae is related to the 
72 biological success of the Megatominae remains unresolved. Although information on the impacts 73 of hastisetae on vertebrate predators is lacking, dermestid larvae and Megatominae in particular 74 have been documented as possible source of allergens in human (Mullen and Durden, 2009). Hastisetae and integument fragments carrying them can be contaminants of stored commodities and are present in working and living environments (Hinton, 1945). Hastisetae seem to be involved in allergic reactions through skin contact, ingestion or inhalation; symptoms can vary accordingly to exposition and consist of skin rushes, asthma, conjunctivitis and digestive system inflammation (Gorgojo et al., 2015; MacArthur et al. 2016). Correlation between the presence of hastisetae and the incidence of allergies in humans exists but the scarce and incomplete information available do not allow to consider hastisetae as a major hazard in living and working places. The aim of this review is to synthesize the knowledge on the hastisetae of dermestid beetles, to evaluate their occurrence in the group and their ecological importance, and to assess their possible implications in the human health. Finally, future perspectives on the study of the hastisetae with special emphasis on Megatominae are envisaged.

\section{Survey methodology}

In order to compile and then review the most exhaustive literature on hastisetae we performed a careful and reiterated research in Google Scholar and Scopus through the use of keywords such as "hastisetae", "Dermestidae", "defense", "larva", integrated by the usage the Boolean operators AND, OR, NOT and the use of " " for specific word combinations. The literature not available online has been recovered thanks to Network Inter-Library Document Exchange (NILDE), a web-based software for the service of Document Supply and Inter-Library Loan, managed by the Italian National Research Council. Our research has enabled the collection of more than a hundred publications, of which ninety were considered in the realization of this review. The library created was comprehensive of literature in English, German and French.

\section{Results}

\section{Hastisetae, structure and function}

100 Hastisetae (or hastate setae) have been cited in several papers dealing with Dermestidae

101 systematics (Rees, 1943; Kiselyova and McHugh, 2006), species identification (Booth et al. 
103 information available concerning their microstructure (Elbert, 1976; 1978), function (Nutting and

104 Spangler, 1969; Mills and Partida, 1976) and evolution (Zhantiev, 2000; Kiselyova and McHugh,

105 2006) is quite scarce. These hairs, located on the dorso-lateral surface of the tergites of larvae

106 and pupae (Fig. 1) (Rees, 1943; Beal, 1960; Kiselyova and McHugh, 2006; Kadej, 2012a, Kadej,

107 2012b; Kadej and Jaroszewicz 2013, Kadej, et al. 2013; Kadej and Guziak 2017; Kadej 2017;

108 2018a, b), are generally quite small with an estimated length, according to the literature, between

109150 and $900 \mu \mathrm{m}$. Density and distribution of the hastisetae vary substantially not only among

110 genera and species but also among tergites of the same species. The hastisetae of the thoracic

111 segments are generally scattered and in low numbers in respect to the other parts of the body.

112 While the abdominal tergites present a wider distribution pattern, from hastisetae covering the

113 major part the tergal disc up to proper setae fields located at the posterior corners of tergites (i.e.

114 Reesa, Trogoderma). In some larvae, the hastisetae give origin to real tufts of hairs located on

115 the posterior corners of the terga IV-VII (i.e. Ctesias) or V-VII (i.e. Anthrenus) (Mroczkowski,

116 1975; Kadej et al. 2013; Kadej 2017; 2018a, b). The hastisetae are inserted in setal sockets on the

117 integument and are connected to the tormogen cell trough the pedicel (Elbert, 1978). The pedicel

118 is the breaking point of the shaft which allows the detachment of the hastiseta (Elbert, 1978).

119 Hastisetae microstructure consists of two main parts: the shaft and the apical head (Fig. 1). The

120 shaft is long and filiform, subcylindrical in section. It is made by repeated modules, from 5 to 77 ,

121 each of them constituted by one cylindrical segment provided with one wreath of spines/scales in

122 the distal part (Elbert, 1978). These spines/scales are postero-laterally oriented and can vary in

123 number from five to seven (Elbert, 1978). The last module of the shaft is generally bigger and

124 thicker than the previous and can slightly vary in general shape to the others; this structure,

125 however, has not been characterized yet. The head of the seta is a subconical anchor-like, spear-

126 shaped structure subdivided longitudinally in sections; the apex of the head is blunt (Elbert,

127 1976; 1978) (Fig. 1). The head consists of five to seven longitudinal, circularly arranged,

128 elements separated from each other by one deep groove, connected to the stem in the upper half

129 by cross-bracing and free in the lower part. The "anchor-like head", set against the thorns of the

130 last shaft module, is involved in entangling invertebrate body parts (Nutting and Spangler, 1969),

131 functioning as trap for antennae, legs, mouthparts, setae and spines (Mills and Partida, 1976).

132 This structure is apparently species specific, varying in shape and length between taxa (Elbert,

133 1976; Kiselyova and McHugh, 2006; Kadej et al. 2013; Kadej 2017; 2018a). The shaft allows 
134 setae to cluster together amplifying the "trapping" effect and the spines increases friction and

135 entangling among hastisetae and between setae and body parts. The combined action of several

136 hastisetae affects small predators (Nutting and Spangler, 1969) and possibly food competitors

137 (Kokubu and Mills, 1980). These setae are hollow (Elbert, 1976; 1978) and could potentially

138 contain proteins or other chemicals involved in the defense, as it has been shown in Lepidoptera

139 (Battisti et al., 2011). Hastisetae morphology and distribution, combined together with other

140 characters, constitute a useful tool for species identification (Rees, 1943; Beal, 1960; Peacock,

141 1993, Kadej, 2012a, b; Kadej and Jaroszewicz 2013, Kadej, et al., 2013; Kadej and Guziak 2017;

142 Kadej 2017; 2018a, b).

143

144 Hastisetae in the systematic and ecology of Dermestidae

145 Dermestidae is a cosmopolitan, comparatively small family of Coleoptera, regarded as 'a well-

146 defined, monophyletic group' (Lawrence and Newton, 1982), consisting of six subfamilies:

147 Orphilinae, Thorictinae, Dermestinae, Attageninae, Trinodinae and Megatominae (Hava, 2015)

148 (Fig. 2). Dermestids are homogeneous only in general appearance, hiding a complex and rich

149 diversity in term of morphological, ecological and ethological aspects. Specific traits and

150 evolutionary tendencies could be observed in several lineages, associated to ecological groups

151 and niches (Zhantiev, 2009); these traits can be observed at adult (Zhantiev, 2000) and larval

152 stage (Kiselyova and McHugh, 2006). Orphilinae are mycetophagous, with sclerotized

153 burrowing larvae (Lenoir et al., 2013). Thorictinae are myrmecophilous and larvae protection is

154 provided by the associated ant species (Lenoir et al., 2013). Dermestinae, the basal group of the

155 "necrophagous clade" (sensu Zhantiev, 2009), have larvae feeding on fresh or relatively humid

156 animal remains (over 15\% in water content) (Zhantiev, 2009). Since Dermestinae food resource

157 is highly perishable, the larvae develop rapidly and persist only for short periods. The oblong,

158 sub-cylindrical and sclerotized larvae of this subfamily can dig through the feeding substrate and

159 live in butyric fermentation condition, under animal remains. It's is plausible that the absence of

160 hastisetae on larval tergites is directly attributable to their burrowing lifestyle. Anchor-like

161 detachable setae could be disadvantageous to move within the substrate. Hastisetae would in fact

162 create friction and would be systematically lost, requiring an important energy expenditure

163 necessary for their replacement. The defensive strategy in Dermestinae is based on the fast

164 escape behavior and the sclerotized integuments of the body. The larvae specifically require the 
165 pupation chamber to molt and they are capable to dig into soil and/or substrate in case of lacking 166 suitable places where to hide. The pupae of this subfamily present gin-traps on the integuments, 167 as a defensive system against predators (Hinton, 1946; Kiselyova and McHugh, 2006) (Fig. 2).

168 Attageninae have burrowing larvae associated to wood dust, fissures of rocks and sandy

169 environments and feed off of insects and other arthropods remains; the larvae are oblong-

170 fusiform with integuments covered of three different kind of hairs (Zhantiev, 2000; Kiselyova

171 and McHugh, 2006). The larvae show a fast escape behavior, similar to Dermestinae.

172 Attageninae prefer to pupate in hidden niches and the pupae bear gin-traps in most of the cases

173 (Zhantiev, 2000). Trinodinae are inquiline of animals' nets: rodent borrows with larvae phoretic

174 on mammal (Zhantiev, 2009) or larvae associated to spider nests (Beal, 1959; Kadej, 2011). The

175 hastisetae, with the single exception of the genus Trinodes (Trinodinae), in which modified

176 hastisetae are described (Kiselyova and McHugh, 2006), are prerogative of the Megatominae

177 larvae and they are strictly associated to larval and pupal morphology and behavior (Kiselyova

178 and McHugh, 2006; Zhantiev, 2009) (Fig. 2). Megatominae is the richest in species subfamily

179 within Dermestidae and its biological success is most probably attributable to the hastisetae

180 occurrence. Amber fossils indicate that hastisetae morphology is highly conserved and remained

181 virtually unchanged since late Cretaceous (Poinar and Poinar, 2016). This group shows a

182 remarked investment on hastisetae as a defensive tool (Nutting and Spangler 1969; Mills and

183 Partida, 1976), exploiting their resistance and durability over time to protect both larvae and

184 pupae (Kiselyova and McHugh, 2006; Zhantiev, 2009). Megatominae is the clade within the

185 xerophilous necrophagous dermestids (sensu Zhantiev, 2009), which can survive on low-water

186 food resources, especially chitinous and keratinous remains (Armes, 1990; Beal, 1998; Zhantiev,

187 2009). These substrates are capable to stand in the environment for a long time but the poor

188 nutrients prolong the duration of larval development, with major implications on morphology,

189 ethology and defensive behavior. Lengthening of the larval phase and its persistence in the

190 environment for a long time has promoted the evolution of morphological and ethological

191 features in Megatominae that otherwise would have been disadvantageous in a different lifestyle.

192 The inability of the larvae to delve into the living substrate (Zhantiev, 2009) favored the

193 evolution of defensive structures (hastisetae) with low energy investment for their synthesis and

194 to remain functional even after being dispersed in the environment. Over time, energetic

195 investment in cuticularized integuments in larvae and gin-traps in pupae shifted to the 
196 morphology of hastisetae and its defense mechanisms. Hastisetae provide protection in both

197 larvae and pupae, favoring a positive energy trade-off in larval development. All the larvae of

198 this subfamily are stout, feebly sclerotized, slow moving and present an aggressive, non-escaping

199 defensive behavior (Kiselyova and MchHugh, 2006). In a disturbance, the larva stops moving,

200 arches its body and spread the hastisetae, frequently from the posterior part of the body where it

201 is densely packed with hastisetae towards the stimulus (Kiselyova and MchHugh, 2006). In

202 general, Megatominae do not make pupation chambers or hide, but simply pupate where they

203 have been feeding. Pupae completely lack gin-traps and remain protected inside the last larval

204 exuvia, completely covered in hastisetae (synapomorphy of Trinodinae + Megatominae)

205 (Kiselyova and McHugh, 2006) (Fig. 2). Megatominae have been able to adapt against

206 interspecific and intraspecific competition for food resources. A common trait associated with

207 the evolution of the hastisetae in the dermestids is, in the necrophagous clade, the transition from

208 scavenger habits of adults to anthophily or aphagy (Zhantiev, 2009) (Fig. 2).

209

210 Hastisetae and human health

211 The capability to feed on a wide range of food resources scarce in water content and to resist to

212 prolonged starvation makes Megatominae larvae the perfect candidate to inhabit working and

213 living spaces. In addiction, due to their slow movements and cryptic behavior these larvae result

214 difficult to detect and remove. For this reason, some species are now synanthropic and

215 cosmopolitan (Bouchet et al., 1996; Gamarra et al., 2009), having been spread all over the world

216 with trade. These species became serious pests, causing considerable loss and damage to stored

217 goods of both animal and plant origin (Hinton, 1945; Burges, 1959; Kantack and Staples, 1969;

218 Mroczkowski, 1975; Beal, 1991; Veer et al., 1991a, b; Veer and Rao, 1995; Veer et al., 1996;

219 Imura, 2003; Rajendran and Hajira Parveen, 2003; Lawrence and Slipinski, 2010) and to objects

220 of organic origin in museums of cultural and natural history (Jurecka, 1987; Zaitseva, 1987;

221 Armes, 1988; Bousquet, 1990, Pinniger and Harmon, 1999; Stengaard Hansen et al., 2012;

222 Quarner, 2015). The hastisetae released by the larva throughout its entire development and

223 abandoned in the environment in association to the exuviae are an important contaminant in

224 dwelling, public spaces as well as food stuff (Gorham, 1979; 1989; Burgess, 1993) and can

225 contribute as allergens in humans (Wiseman et al., 1959; Johansson et al., 1985; Baldo and

226 Panzani, 1988; Burgess, 1993; Gorgojo et al., 2015; McArthur et al., 2016): chitin, likely the 
227 main constituent of the hastisetae, is in fact a powerful and widely recognized allergen, and its 228 interaction with Th2 lymphocytes and human chitinases enhances the inflammation process 229 (Brinchmann et al., 2011; Bucolo et al., 2011; Mack et al., 2015). However, it is still unclear 230 whether the inflammatory effect of the hastisetae is attributable to the mechanical action of the 231 seta and its penetration through the epithelia or if it is associated to the presence of specific 232 molecules capable to start an immunological reaction. Hastisetae have been directly linked to 233 occupational diseases in working environments (Loir and Legagneux 1922; Renaudin, 2010), 234 especially when processing organic materials such flour, wool, silk and other commodities (Veer 235 et al., 1996; Brito et al., 2002), or stored objects of organic origin in museums and art galleries 236 (Siegel et al. 1991). The exposure to and inhalation of hastisetae, even in the form of dust, are 237 reported to cause rhinoconjunctivitis (Brito et al., 2002) and asthma (Cuesta-Herranz et al., 238 1997; Brito et al., 2002; Bernstein et al., 2009). Megatominae are also one of the arthropod 239 groups most commonly recorded inside houses (Gamarra et al., 2009; Bertone et al., 2016; Madden et al. 2016); the larvae persist in these environments for months, even for years, feeding on food (Gorham, 1979; 1989; Hirao, 2000), pet food (Rudolph et al., 1981), dust, insect remains and clothes, especially wool fabric (Bouchet et al., 1996). This prolonged presence inside houses together with the persistence of the hastisetae in the environment greatly increase the possibility for the humans to come into contact and develop a sensitization to these detachable hairs (Wiseman et al., 1959; Kaufman et al., 1986; Burgess, 1993; Jakubas-Zawalska et al., 2016). The direct exposure of hastisetae to the skin, maybe due to contaminated bed or clothes, causes severe dermatitis (Sheldon and Johnston, 1941; Cormia et al., 1945; Okamura, 1967; Ahmed et al., 1981; Alexander, 1984; Johansson et al., 1985; Southcott, 1989; Horster et al., 2002; Zanca et al., 2012; Hoverson et al., 2015; McArthur et al., 2016), while the repeated inhalation over a longer period may cause asthma (Cuesta-Herranz et al., 1997; Brito et al., 2002; Bernstein et al., 2009). Food contamination and hastisetae ingestion has been proved to cause the inflammation of the digestive system, manifesting through nausea, fever, diarrhea (Hirao, 2000), proctitis and perianal itching (Krause et al., 1998). Unusual, and apparently asymptomatic findings of hastisetae have been done on sputum (Johnson and Batchelor, 1989) and cervical specimens (Bechtold et al., 1985; Bryant and Maslan, 1994; Williamson et al., 2005). The incidence of pathologies associated with Dermestidae and Megatominae in particular, seems to be considerably reduced in recent decades probably due to the increased degree of 
258 attention regarding the presence of contaminants in food and the marked improvement in the

259 processes of conservation and storage of raw materials; the development of adequate plans for

260 monitoring and management of pests and the general improvement in the quality of life of people

261 associated with greater healthiness of the houses have contributed further to the imitation of the

262 impact (Athanassiou and Arthur, 2018). However, there is also the possibility that many

263 domestic cases of exposure to hastisetae, especially in the case of skin rushes (erythematobullous

264 reactions) may be under-recognized and underdiagnosed, due to similar effects to attacks by

265 other arthropods (Burgess, 1993; McArthur et al., 2016). Furthermore, almost all the cases

266 reported in the medical literature regard developed countries while the effect of hastisetae on

267 human health in developing countries remains almost obscure and widely understudied.

268 Undoubtedly, a better knowledge of the inflammation caused by hastisetae would allow the

269 recommendation of appropriated prevention measures and the formation of medical personnel

270 able to provide early diagnosis and administration of appropriate therapies. Moreover, a close

271 collaboration between occupational physicians, entomologists and immunologists could be of

272 great help for the development of new surveillance programs and new health and safety

273 guidelines for workers and people most at risk.

274

275 Conclusions

276 The scant information about the fine morphology and the ecological roles of hastisetae, and their

277 implications in human health opens a whole horizon of research possibilities. Hastisetae

278 morphology is undoubtedly the starting point for any future study. The characterization of

279 hastisetae through electron microscopy and micro-CT is the basic and fundamental step to

280 understand their functional morphology. The identification of specific morphological traits in the

281 hastisetae will help to solve Megatominae systematics, highlighting the evolution of these

282 structures in relation to phylogeny and biology. A detailed knowledge of hastisetae morphology

283 will allow us to understand the defensive mechanism and if it acts similarly in all Megatominae.

284 Comparing reactions of different predators to hastisetae will be useful to evaluate the different

285 effects and particularly if this defensive system is primarily directed towards invertebrates and/or

286 to vertebrates. Are humans or other vertebrates possible targets of hastisetae, and if so what are

287 the causes of the unpleasant side-effects in humans? Is it the penetration of these setae trough

288 epithelia the main cause of inflammation and are there any particular substance inducing the 
289

290

291

292

293

294

295

296

297

298

299

300

301

302

303

304

305

306

307

308

309

310

311

312

313

314

315

316

317

318

319

320

321

322

323

324

325

reaction, as it has been showed in Lepidoptera? Chemical analysis of secretions can identify and characterize the compounds responsible of the inflammation in humans and clarify their possible role as adjuvants in defense against the threats. Understanding the causes of allergic responses in humans will allow the development of specific medical therapies. Hastisetae could become an important addition in species identification, with relevant application in forensic entomology and pest management on stored products. Furthermore, the creation of a molecular fingerprint based on hastisetae content can aid in developing tools to detect insect fragments in contaminated stored products, especially food.

\section{Acknowledgements}

Thanks to Mizuki Uemura (Università degli Studi di Padova) for language editing, to Paolo Paolucci (Università degli Studi di Padova) and Michał Kukla (University of Wrocław) for images realization, to Antonio Masi (Università degli Studi di Padova) and three anonymous referees for useful suggestion provided during manuscript realization.

\section{References}

Ahmed R, Moy R, Barr R, Prince Z. 1981. Carpet beetle dermatitis. Journal of the American Academy of Dermatology 5: 428-432. 10.1016/S0190-9622(81)70104-X

Alexander JD. 1984. Arthropods and human skin. London: Springer.

Armes NJ. 1988. The seasonal activity of Anthrenus sarnicus Mroczkowski (Coleoptera: Dermestidae) and some other beetle pests in the museum environment. Journal of Stored Products Research 24: 29-37. 10.1016/0022-474X(88)90006-9

Armes NJ. 1990 The biology of Anthrenus sarnicus Mroczkowski (Coleoptera: Dermestidae): I. Egg and larval development. Journal of Stored Products Research 26: 1-22. 10.1016/0022-474X(90)90033-O

Athanassiou C, Arthur F. 2018. Recent Advances in Stored Product Protection. Springer, Berlin, Heidelberg. 10.1007/978-3-662-56125-6

Ayres S, Mihan R. 1967. Delusions of parasitosis caused by carpet beetles. JAMA 199: 675. 10.0.3.233/jama.1967.03120090117036

Baldo BA, Panzani RC. 1988 Detection of IgE Antibodies to a Wide Range of Insect Species in Subjects with Suspected Inhalant Allergies to Insects. International Archives of Allergy and Immunology 85:278-287 10.1159/000234518

Barth FG. 2004. Spider mechanoreceptors. Current Opinion in Neurobiology 14: 415-422. 10.1016/j.conb.2004.07.005

Battisti A, Holm G, Fagrell B, Larsson S. 2011. Urticating hairs in arthropods: their nature and medical significance. Annual Review of Entomology 56: 203-220. 10.1146/annurev-ento120709-144844 
326

327

328

329

330

331

332

333

334

335

336

337

338

339

340

341

342

343

344

345

346

347

348

349

350

351

352

353

354

355

356

357

358

359

360

361

362

363

364

365

366

367

368

369

370

Beal RS. 1959. Notes on the biology and systematics of the dermestid beetle genus Apsectus with descriptions of two new species. Annals of the Entomological Society of America 52: 132-137. 10.1093/aesa/52.2.132

Beal RS. 1960. Descriptions, biology, and notes on the identification of some Trogoderma larvae (Coleoptera, Dermestidae). United States Department of Agriculture. Technical Bulletin 1228: $1-26$.

Beal RS. 1991. Dermestidae (Bostrichoidea) (including Thorictidae, Thylodriidae). In: Stehr, FW, ed. Immature Insects. Vol. 2. Dubuque: Kendall/Hunt, IA, 434-439.

Beal RS. 1998. Taxonomy and biology of nearctic species of Anthrenus (Coleoptera: Dermestidae). Transactions of the American Entomological Society 124: 271-332.

Bechtold E, Staunton CE, Katz SS. 1985. Carpet beetle larval parts in cervical cytology specimens. Acta Cytologica 29: 345-352.

Bereiter-Hahn J, Matoltsy AG, Richards KS. 1984. Biology of the integument, Vol. 1. Invertebrates. Berlin: Springer-Verlag.

Bernstein JA, Morgan MS, Ghosh D, Arlian L. 2009. Respiratory sensitization of a worker to the warehouse beetle Trogoderma variabile: An index case report. Journal of Allergy and Clinical Immunology 123: 1413-1416. 10.1016/j.jaci.2009.04.006

Bertani R, Guadanucci JPL. 2013. Morphology, evolution and usage of urticating setae by tarantulas (Araneae: Theraphosidae). Zoologia 30: 403-418. 10.1590/S198446702013000400006

Bertone MA, Leong M, Bayless KM, Malow TLF, Dunn RR, Trautwein MD. 2016. Arthropods of the great indoors: characterizing diversity inside urban and suburban homes. PeerJ 4:e1582 h10.7717/peerj.1582

Booth RG, Cox ML, Madge RB. 1990.Guides to insects of importance to man. No. 3. Coleoptera. Wallingford: CAB International.

Bouchet F, Lavaud F, Deschamps F. 1996. Coléoptères synanthropes des moquettes et autres textiles domestiques. Revue Française d'Allergologie et d'Immunologie Clinique 36: 765770. 10.1016/S0335-7457(96)80063-3

Bousquet Y. 1990. Beetles associated with stored products in Canada: An identification guide. Ottawa: Canadian Government Publishing Centre.

Brinchmann BC, Bayat M, Brøgger T, Muttuvelu DV, Tjønneland A, Sigsgaard T. 2011. A possible role of chitin in the pathogenesis of asthma and allergy. Annals of Agricultural and Environmental Medicine 18: 7-12.

Brito F, Mur P, Barber D, Lombardero M, Galindo P, Gómez E, Borja J. 2002. Occupational rhinoconjunctivitis and asthma in a wool worker caused by Dermestidae spp. Allergy 57: 1191-1194. 10.1034/j.1398-9995.2002.23676.x

Bryant J, Maslan A. 1994. Carpet beetle larval parts in pap smears: report of two cases. Southern Medical Journal 87:763-764.

Bucolo C, Musumeci M, Musumeci S, Drago F. 2011. Acidic mammalian chitinase and the eye: implications for ocular inflammatory diseases. Frontiers in Pharmacology 2: 1-4. 10.3389/fphar.2011.00043

Burges HD. 1959. Studies on the dermestid beetle, Trogoderma granarium Everts: Ecology in malt stores. Annals of Applied Biology 47: 445-462. 10.1111/j.1744-7348.1959.tb07278.x

Burgess I. 1993. Allergic reaction to Arthropods. Indoor and Built Environment 2: 64-70. $10.1177 \% 2 \mathrm{~F} 1420326$ X9300200202 
371

372

373

374

375

376

377

378

379

380

381

382

383

384

385

386

387

388

389

390

391

392

393

394

395

396

397

398

399

400

401

402

403

404

405

406

407

408

409

410

411

412

413

414

Cormia FE., Lewis GM. 1948. Contact dermatitis from beetles, with a report of a case due to the carpet beetle (Anthrenus scrophulariae). New York state journal of medicine 48: 203712039.

Cuesta-Herranz J, de las Heras M, Sastre J, Lluch M, Fernández M., Lahoz C, Alvarez-Cuesta E. 1997. Asthma caused by Dermestidae (black carpet beetle): A new allergen in house dust. Journal of Allergy and Clinical Immunology 99: 147-149. 10.1016/S00916749(97)70311-7

Eisner T, Eisner M, Deyrup M. 1996. Millipede defense: use of detachable bristles to entangle ants. Proceedings of the National Academy of Sciences of the United States of America 93: 10848-10851. 10.1073/pnas.93.20.10848

Elbert A. 1976. Elektronenmikroskopische untersuchungender pfeilhaare verschiedener arten der Anthreninae (Col. Dermestidae). Anzeiger Schadlingskunde Pflanzenschutz Umweltschutz 49: 81-83. 10.1007/BF01985639

Elbert A. 1978. Die pfeilhaare der Megatominae (Col., Dermestidae): ein abwehrsystem. Anzeiger Schadlingskunde Pflanzenschutz Umweltschutz 51: 109-110. 10.1007/BF01903308

Felgenhauer EB, Watling L, Thistle AA. 1989. Functional morphology of feeding and grooming in crustacea. (Crustacean Issues 6. General editor: Frederick R. Schram). Rotterdam: Brookfield, A. A. Bakema.

Gamarra P, Outerelo R, Hernández JM. 2009. Coleópteros en las viviendas de la zona centro de España (Insecta, Coleoptera). Boletín de la Real Sociedad Española de Historia Natural. Seccion Biologica 103: 87-101.

Garm A, Watling L. 2013. The crustacean integument: setae, setules, and other ornamentation. In: Watling L, Thiel M, ed. Functional Morphology and Diversity. The Natural History of the Crustacea series, volume 1. Oxford: Oxford University Press, 167-198

Garm A. 2004a. Mechanical functions of setae from the mouth apparatus of seven species of decapod crustaceans. Journal of Morphology 260: 85-100. 10.1002/jmor.10213

Garm A. 2004b. Revising the definition of the crustacean seta and setal classification systems based on examinations of the mouthpart setae of seven species of decapods. Zoological Journal of the Linnaean Society 142: 233-252. 10.1111/j.1096-3642.2004.00132.x

Gorgojo IE, De Las Heras M, Pastor C, Cuesta Herranz J, Sanz Maroto A. 2015. Allergy to Dermestidae: A new indoor allergen? Journal of Allergy and Clinical Immunology 135: Supplement, Page AB105. 10.1016/j.jaci.2014.12.1278

Gorham JR. 1979. The significance for human health of insects in food. Annual Review of Entomology 24: 209-224. 10.1146/annurev.en.24.010179.001233

Gorham JR. 1989. Foodborne Filth and Human Disease. Journal of Food Protection 52: 674677. 10.4315/0362-028X-52.9.674

Hava J. 2015. World catalogue of Insects. Volume 13. Dermestidae (Coleoptera). Leiden/Boston: Brill.

Hinton HE. 1945. A Monograph of the Beetles Associated with Stored Products. Vol. 1. London: British Museum (Natural History).

Hinton HE. 1946. The "gin traps" of some beetle pupae; a protective device which appears to be unknown. Transactions of the Entomological Society of London 97: 473-496. 10.1111/j.1365-2311.1946.tb00273.x

Peer) reviewing PDF | (2019:06:38833:2:0:NEW 22 Nov 2019) 
415 Hirao M. 2000. Warehouse Beetle, Trogoderma variabile Baillon (Coleoptera: Dermestidae),

416

417

418

419

420

421

422

423

424

425

426

427

428

429

430

431

432

433

434

435

436

437

438

439

440

441

442

443

444

445

446

447

448

449

450

451

452

453

454

455

456

457

458

459
Associated with Stored Product Pest and Human Illness. Urban Pest Management 22: 821. [in Japanese]

Horster S, Prinz JC, Holm N, Wollenberg A. 2002. Anthrenus-dermatitis. Hautarzt, 53: 328-331.

Hoverson K, Wohltmann WE, Pollack RJ, Schissel DJ. 2015. Dermestid dermatitis in a 2-Yearold girl: case report and review of the literature. Pediatric Dermatology 32(6): 228-233. $\underline{10.1111 / \text { pde. } 12641}$

Hultgren KM, Stachowicz JJ. 2008. Alternative camouflage strategies mediate predation risk among closely related co-occurring kelp crabs. Oecologia 155, 519-528.

$10.1007 / \mathrm{s} 00442-007-0926-5$

Imura O. 2003. Insect pests of stored products in East Asia (Japan and Korea). In: Prakash A, Rao J, Jayas DS, Allotey J, ed. Insect Pests of Stored Products: A Global Scenario. Cuttack: Applied Zoologists Research Association, 203-216.

Jakubas-Zawalska J, Asman M, Kłyś M, Solarz K. 2016. Sensitization to Sitophilus granarius in selected suburban population of South Poland. Journal of Stored Products Research 69: 1-6. 10.1016/j.jspr.2016.05.006,

Johansson SG, Wüthrich B, Zortea-Caflisch C. 1985. Nightly asthma caused by allergens in silkfilled bed quilts: clinical and immunologic studies. Journal of Allergy and Clinical Immunology 75: $452-459$ 10.1016/S0091-6749(85)80017-8

Johnson FP, Batchelor J. 1989. Carpet beetle larval hairs in a sputum cytology specimen. Acta Cytologica 33:286.

Jurecka W, Gebhart W, Mainitz M. 1987. Anthrenus sp. The paraffin block eater bug. The American Journal of Dermatopathology 9: 204-207.

Kadej M, Guziak J. 2017. Description of the larva of Globicornis emarginata (Gyllenhal, 1808) (Dermestidae: Megatominae). Annales Zoologici 67: 749-757. 10.3161/00034541ANZ2017.67.4.010

Kadej M, Jaroszewicz S. 2013. Detailed morphological description of the mature larva of Globicornis corticalis (Eichhoff, 1863) (Dermestidae: Megatominae) with comparisons to related species. Zootaxa 3686: 556-564. 10.11646/zootaxa.3686.5.4

Kadej M. 2012a. Detailed morphological description of the mature larva of Anthrenus latefasciatusReitter, 1892 (Dermestidae: Megatominae: Anthrenini) with comparisons to related species. Zootaxa 3270: 31-40. 10.11646/zootaxa.3270.1.2

Kadej M. 2012b. Detailed description of the morphology of the last instar larva of Trogoderma megatomoides Reitter, 1881 (Dermestidae: Megatominae: Megatomini) with comparison to related species. Journal of the Kansas Entomological Society 85: 5-13. 10.2317/JKES110707.1

Kadej M. 2017. Larva and pupa of Megatoma (s. str.) undata (Linnaeus, 1758) with remarks on biology and economic importance (Coleoptera, Dermestidae). Zookeys 698: 54-79. 10.3897/zookeys.698.14049

Kadej M. 2018a. Contribution to knowledge of the immature stages of Dermestidae with special emphasis on the larval morphology of the genus Anthrenus Geoffroy, 1762 (Megatominae: Anthrenini). Poznan: Polish entomological Monographs.

Kadej M. 2018b. Larva and pupa of Ctesias (s.str.) serra (Fabricius, 1792) with remarks on biology and economic importance, and larval comparison of co-occurring genera (Coleoptera, Dermestidae). ZooKeys 758: 115-135. 10.3897/zookeys.758.24477 
460 Kadej M. Jaroszewicz, S, Tarnawski D. 2013. Comparative morphology and biology of mature

461

462

463

464

465

466

467

468

469

470

471

472

473

474

475

476

477

478

479

480

481

482

483

484

485

486

487

488

489

490

491

492

493

494

495

496

497

498

499

500

501

502

503

504 larvae in the genus Anthrenus (Dermestidae: Megatominae: Anthrenini) with comparisons to related species. Annales de la Société Entomologique de France 49: 244256. $10.1080 / 00379271.2013 .845472$

Kantack BH, Staples R. 1969. The biology and ecology of Trogoderma glabrum (Herbst) in stored grains. Lincoln: Research Bulletin 232. Lincoln, Nebraska, University of Nebraska.

Kaufman GL, Bado BA, Tovey ER. 1986. Inhalant allergy following occupational exposure to blow flies. Clinican and experimental Allergy 16: 65-71. 10.1111/j.13652222.1986.tb01955.x

Keil TA, Steinbrecht RA. 1984. Mechanosensitive and olfactory sensilla of insects. In: King RC, Akai H, ed. Insect Ultrastructure, Vol. 2. New York: Plenum Press, 477-516.

Keil TA. 1997. Functional morphology of insect mechanoreceptors. Microscopy Research and Technique 39: 506-531 10.1002/(SICI)1097-0029(19971215)39:6\%3C506::AIDJEMT5\%3E3.0.CO;2-B

Kiselyova T, McHugh JV. 2006. A phylogenetic study of Dermestidae (Coleoptera) based on larval morphology. Systematic Entomology 31: 469-507. 10.1111/j.13653113.2006.00335.x

Kokubu H, Mills RS. 1980. Susceptibility of thirteen stored product beetles to entanglement by Trogoderma hastisetae. Journal of Stored Products Research 16: 87-92. 10.1016/0022474X(80)90002-8

Krause R, Reisinger EC, Zenahlik P, Krejs GJ. 1998. The beetle Anthrenus verbasci causing proctitis and perianal itching. Scandinavian Journal of Gastroenterology 33: 894-895.

Labarque FM., Wolff JO, Michalik P, Griswold CE. Ramirez MJ. 2017. The evolution and function of spider feet (Araneae: Arachnida): multiple acquisitions of distal articulations. Zoological Journal of the Linnean Society 181: 308-341. 10.1093/zoolinnean/zlw030

Lawrence JF, Slipinski A. 2010. Dermestidae Latreille, 1804. In: Leschen RAB, Beutel RG, Lawrence JF, ed. Coleoptera, beetles. Volume 2: Morphology and systematics (Elateroidea, Bostrichiformia, Cucujiformiapartim). Berlin: Walter de Gruyter, 198-206.

Lawrence JF. Newton AF. 1982. Evolution and classification of beetles. Annual Review of Ecology and Systematics 13: 261-290. 10.1146/annurev.es.13.110182.001401

Lenoir A, Háva J, Hefetz A, Dahbi A, Cerdá X, Boulay R. 2013. Chemical integration of Thorictus myrmecophilous beetles into Cataglyphis ant nests. Biochemical Systematics and Ecology 51: 335-342. 10.1016/j.bse.2013.10.002

Loir A, Legagneux H. 1922. Accidents du travail occasionnés par les coléoptères. Bulletin de l'Académie nationale de médecine 88: 68-72.

MacArthur KM, Richardson V, Novoa RA, Stewart CL, Rosenbach M. 2016. Carpet beetle dermatitis: a possibly under-recognized entity. International Journal of Dermatology 55: 577-579. 10.1111/ijd.12952

Mack I, Hector A, Ballbach M, Kohlhäufl J, Fuchs KJ, Weber A, Mall MA, Hartl D. 2015. The role of chitin, chitinases, and chitinase-like proteins in pediatric lung diseases. Molecular and Cellular Pediatrics 2: 1-8. 10.1186/s40348-015-0014-6

Madden AA, Barberan A, Bertone MA, Menninger HL, Dunn R, Fierer N. 2016. The diversity of arthropods in homes across the United States as determined by environmental DNA analyses. Molecular Ecology 25: 6214-6224 doi: 10.1111/mec.13900. 
505

506

507

508

509

510

511

512

513

514

515

516

517

518

519

520

521

522

523

524

525

526

527

528

529

530

531

532

533

534

535

536

537

538

539

540

541

542

543

544

545

546

547

548

549
Mills RB, Partida GJ. 1976. Attachment mechanisms of Trogoderma hastisetae that make possible their defensive function. Annals of the Entomological Society of America 69: 2933. 10.1093/aesa/69.1.29

Mullen G, Durden I. 2009. Medical and Veterinary Entomology, Second Edition. London: Academic.

Mroczkowski M. 1975. Dermestidae, Skórnikowate (Insecta: Coleoptera). Fauna Polski. Tom 4. Warsaw: Polska Akademia Nauk. [In Polish]

Neville C. 1975. Biology of the arthropod cuticle. Berlin: Springer Verlag.

Nutting WL, Spangler HG, 1969. The hastate setae of certain dermestid larvae: an entangling defense mechanism. Annals of the Entomological Society of America 62: 763-769.

Okumura GT. 1967. A report of canthariasis and allergy caused by Trogoderma (Coleoptera: Dermestidae). California Vector Views 14: 19-22.

Pauli GJ, Bessot C. 2009.Rare indoor allergens. European Annals of Allergy and Clinical Immunology 41: 99-105. 10.1053/ai.1994.v94.a56012

Peacock ER. 1993. Adults and larvae of hide, Larder and carpet beetles and their relatives (Coleoptera: Dermestidae) and of derodontid beetles (Coleoptera: Derodontidae), Handbooks for the Identification of British Insects. London: Royal Entomological Society of London.

Perez-Miles F, Montes De Oca L, Postiglioni R, Costa FG. 2005. The stridulatory setae of Acanthoscurria suina (Araneae, Theraphosidae) and their possible role in sexual communication: an experimental approach. Iheringia 95: 365-371. 10.1590/S007347212005000400004

Pinniger DB, Harmon JD. 1999. Pest management, prevention and control. In: Carter D, Walker A, eds. Care and Conservation of Natural History Collections. Oxford: Butterwoth Heinemann, 152 - 176.

Poinar GO Jr, Poinar R. 2016. Ancient hastisetae of Cretaceous carrion beetles (Coleoptera: Dermestidae) in Myanmar amber. Arthropod Structure \& Development 45: 642-645. 10.1016/j.asd.2016.10.012

Querner P. 2015. Insect pests and integrated pest management in museums, libraries and historic buildings. Insect, 6: 595-607. 10.3390/insects6020595

Rajendran S, Hajira Parveen KM. 2005. Insect infestation in stored animal products. Journal of Stored Products Research 41: 1-30. 10.1016/j.jspr.2003.12.002

Rees BE. 1943. Classification of the Dermestidae (larder, hide and carpet beetles) based on larval characters, with a key to North American genera. United States Department of Agriculture, Miscellaneous Publications 511: 1-18.

Renaudin J-M. 2010. Allergie aux insects piqueurs et maladie professionnelle. Revue Française d'Allergologie 50: 137-140.

Rudolph R, Blohm B., Kunkel G, Mast H, Muckelmann R, Schniggenberg E. 1981. Futtermittelallergien bei Tierhaltern. In: Christophers E, Goos M eds. XXXII. Tagung gehalten in Westerland/Sylt vom 16. bis 20. September 1980. Verhandlungen der Deutschen Dermatologischen Gesellschaft, vol 32. Springer, Berlin, Heidelberg 10.1007/978-3-642-81671-0_42

Sheldon JM, Johnston JH. 1941. Hypersensitivity to beetles (Coleoptera). Report of a case. Journal of Allergy and Clinical Immunology 12: 493-494. 10.1016/S00218707(41)90228-9

Peer] reviewing PDF | (2019:06:38833:2:0:NEW 22 Nov 2019) 
550

551

552

553

554

555

556

557

558

559

560

561

562

563

564

565

566

567

568

569

570

571

572

573

574

575

576

577

578

579

580

581

582

583

584

585

586

587

588

589

590

591

592

593

594

595

Siegel S, Lee N, Rohr A, Ank B, Rachelefsky G, Spector S, Siegel J. 1991. Evaluation of dermestid sensitivity in museum personnel. Journal of Allergy and Clinical Immunology 1:190. 10.1016/0091-6749(91)91488-F

Southcott RV. 1989. Injuries from Coleoptera. Medical Journal of Australia 151: 654-659. 10.5694/j.1326-5377.1989.tb139642.x

Steinbrech RA. 1984. Arthropoda: chemo-, thermo, and hygroreceptors. In: Bereiter-Hahn J, Matoltsy AG, Richards KS, ed. Biology of the integument, Vol 1. Invertebrates. Berlin: Springer Verlag, 532-553.

Stengaard H, L., Akerlund M, Grontoft T, Rhyl-Svendsen M, Schmidt A, Bergh J, Vagn Jensen, K. 2012. Future pest status of an insect pest in museums, Attagenus smirnovi: distribution and food consumption in relation to climate change. Journal of Cultural Heritage 13: 221-27. 10.1016/j.culher.2011.05.005

Veer V, Negi BK, Rao KM. 1996. Dermestid beetles and some other insect pests associated with stored silkworm cocoons in India, including a world list of dermestid species found attacking this commodity. Journal of Stored Products Research 32: 69-89. 10.1016/0022474X(95)00032-3

Veer V, Prasad R, Rao KM. 1991a. Taxonomic and biological notes on Attagenus and Anthrenus spp. (Coleoptera: Dermestidae) found damaging stored woollen fabrics in India. Journal of Stored Products Research 27: 189-198. 10.1016/0022-474X(91)90044-D

Veer V, Prasad R, Rao KM. 1991b. Studies on insect proofing of woollen fabrics with EulanWA New and permethrin. In: Ramachandran PK, Sukumaran D, Rao SS, ed. Entomology for Defense Services. Proceedings of the Symposium, September 1990. Gwalior, India, 244253.

Veer V, Rao KM. 1995. Taxonomic and biological notes on three Attagenus spp. (Coleoptera: Dermestidae) not previously recorded as pests of stored woollen fabrics in India. Journal of Stored Products Research 31: 211-219. 10.1016/0022-474X(95)00016-Z

Williamson BA, Nicolas MM, Nayar R. 2005. Unusual finding in cervical smear. Archives of Pathology \& Laboratory Medicine 129: 809-809.

Winterton S. 2009. Scales and setae. In: Resh VH, Cardé RT, ed. Encyclopedia of Insects, 2nd ed. 901-904.

Wiseman RD, Woodin WG, Miller HC, Myers MA. 1959. Insect allergy as a possible cause of inhalant sensitivity. Journal of Allergy 30: 191-197.

Zaitseva GA. 1987. Protection of museum textiles and leather against the dermestid beetle (Coleoptera, Dermestidae) by means of antifeedants. Studies in Conservation 32: 176180. 10.1179/sic.1987.32.4.176

Zanca A, Zanca A, Cassisa A. 2012. A case of carpet beetle dermatitis. Giornale Italiano di Dermatologia e Venereologia 147: 216-218.

Zeledón R. Valerio CE, Valerio JE. 1973. The camouflage phenomenon in several species of Triatominae (Hemiptera, Reduviidae). Journal of medical Entomology 10: 209-211. 10.1093/jmedent/10.2.209

Zhantiev RD. 2000. Classification and phylogeny of dermestids (Coleoptera, Dermestidae). Entomological Review 80: 1115-1129.

Zhantiev, R. D. 2009. Ecology and classification of dermestid beetles (Coleoptera, Dermestidae) of the Palearctic fauna. Entomological Review 89: 157-174.

$10.1134 / \mathrm{S} 0013873809020055$

PeerJ reviewing PDF | (2019:06:38833:2:0:NEW 22 Nov 2019) 


\section{Figure 1}

Hastisetae structure and distribution on Megatominae larvae (general scheme):

(a). Example of Megatominae larva (Megatoma undata (Linnaeus, 1758)), dorsal view. T1-T3:

thoracic segments; A1-A8: abdominal segments. (b). Tuft of hastisetae on abdominal segments. (c). Hastisetae, lateral view. (d). Head of the hastiseta (subconical anchor-like, spear-shaped head). Image credit: Paolo Paolucci, Michał Kukla. 

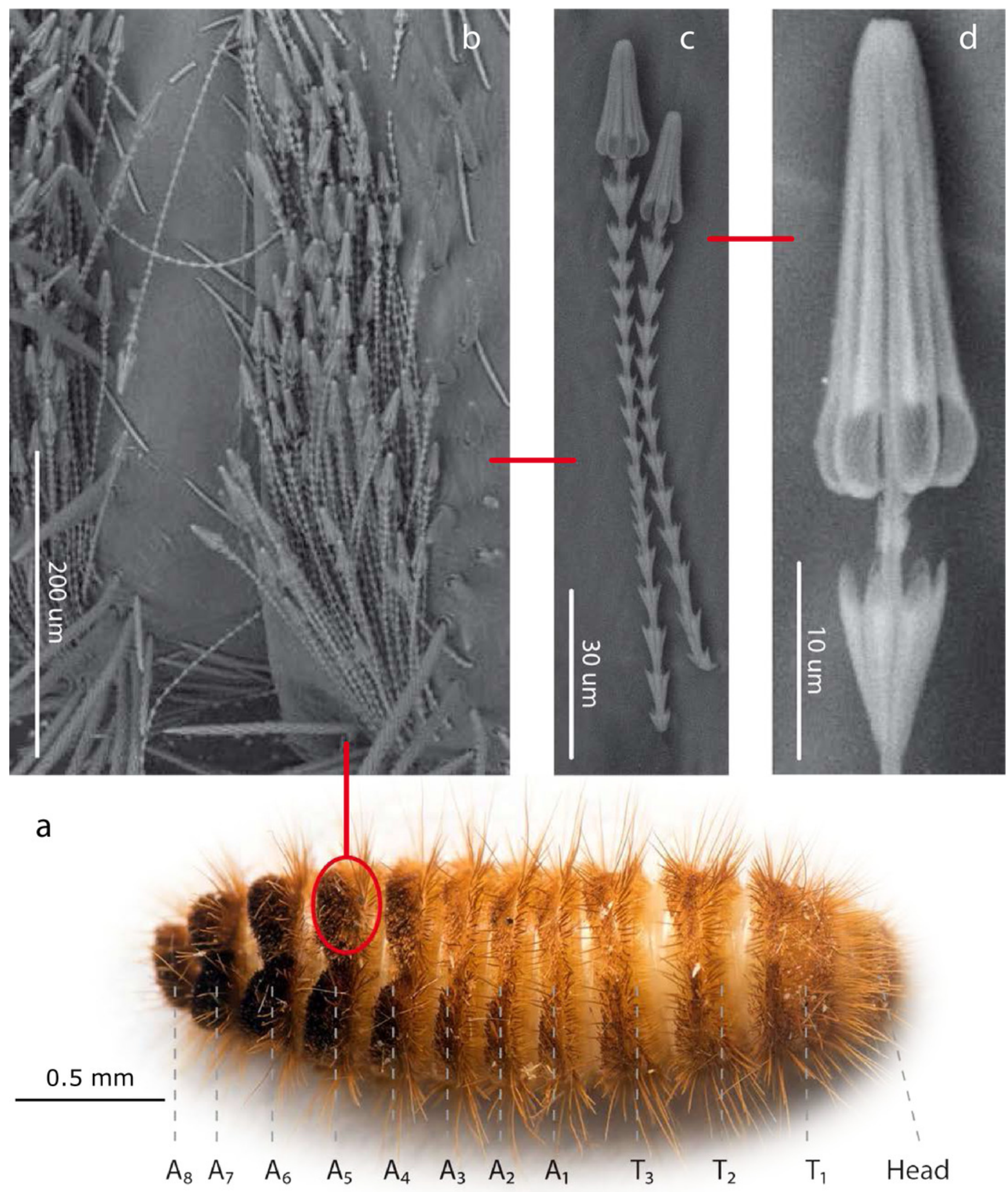


\section{Figure 2}

Schematic representation of Dermestidae phylogeny (based on Kiselyova and McHugh, 2006), with an indication of feeding habits of the adult beetles, duration of larval lifespan, and larval-pupal defensive structures.

The size of the colored bands in each subfamily is an approximated representation of the number of species. Image credit: Paolo Paolucci.

\section{ADULT FEEDING HABITS LARVAL LIFESPAN DEFENSE STRATEGY}

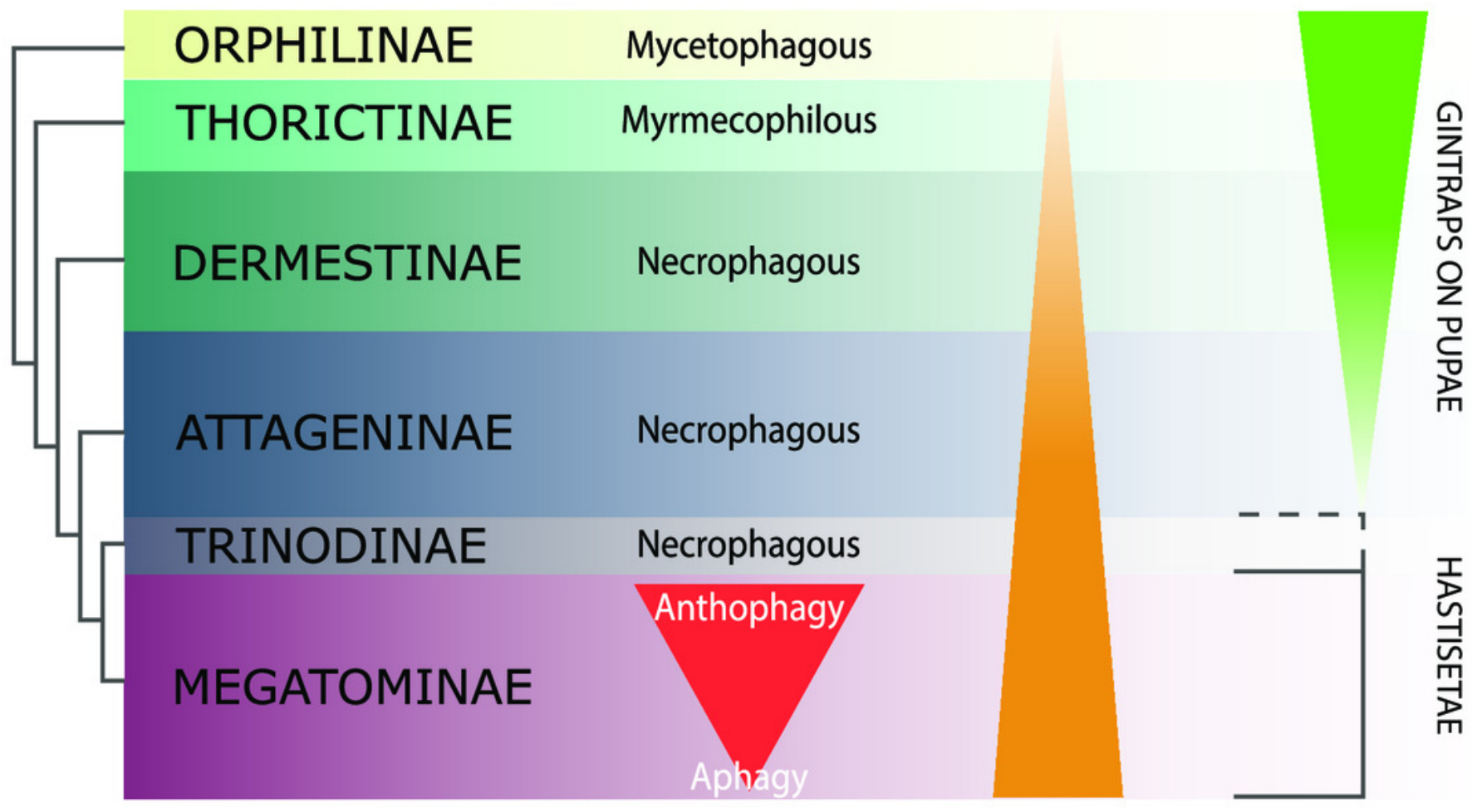

